E-ISSN : 2549-6581

DOI: 10.21776/ub.JOIM.2021.005.02.1

Artikel Hasil Penelitian

Diterima : 10 September 2020

Direview : 5 Februari 2021

Dimuat : Agustus - November 2021

\section{OPEN ACCESS}

Journal of Issues in Midwifer

\title{
Prenatal Attachment pada Kehamilan Remaja dengan Gangguan Penyesuaian dan Retardasi Mental Berat
}

\author{
Frilya Rachma Putri ${ }^{1 *}$, Mayniar Ayu Rahmadianti ${ }^{2}$ \\ ${ }^{\left.{ }^{*}\right)}$ Departemen Psikiatri, Fakultas Kedokteran, Universitas Brawijaya / Rumah Sakit Umum \\ Daerah Dr. Saiful Anwar Malang, email: frilya.yudi@ub.ac.id , Tlp : +62811313188 \\ ${ }^{2)}$ Alumni Fakultas Kedokteran, Universitas Brawijaya
}

\begin{abstract}
Prenatal attachment is an abstract and unidirectional bond between parents and the fetus that develops during pregnancy. It is closely associated with how the mother utilizes her abilities and knowledge to organize and perform the duties related to her maternal role attainment. We report a case of 15 years old girl admitted to the emergency room with an official request of visum et repertum in January 2018 due to becoming suspected sexual violence victim. The history of present illness revealed a 15 y.o. girl G1P0A0, singleton, at 34-36W Estimated Gestational Age with condyloma acuminata. During her pregnancy, she described relatively negative feelings about her pregnancy including shame, anxiety, and anger. She felt lack of energy and motivation since she became aware of her pregnancy, therefore spent her most of her time on the bed. Her IQ-test showed a profound intelligence rate followed by a total score of Strength and Difficulty Questionnaire (SDQ) 16, and scored low in Prenatal Attachment Inventory (PAI) at 31. We concluded that PA scoring can be utilized as a predictor of mother-infant bonding quality after birth, thus the instrument will be beneficial as initial screening before choosing appropriate management for vulnerable population mother.
\end{abstract}

Keywords: prenatal attachment; adolescent pregnancy; adjustment disorders; mental retardation

\begin{abstract}
ABSTRAK
Prenatal Attachment (PA) adalah keterikatan yang abstrak dan bersifat satu arah antara orang tua terhadap calon bayi dalam masa kehamilan. Hal ini erat kaitannya terhadap bagaimana seseorang menggunakan kemampuan dan pengetahuannya dalam menyiapkan diri melakukan kewajiban terkait perannya sebagai orang tua. Sebuah kasus perempuan usia 15 tahun dibawa ke rumah sakit untuk keperluan permintaan visum et repertum pada Januari 2018 dengan dugaan pelecehan seksual. Pemeriksaan fisik didapatkan pasien hamil $\mathrm{G}_{1} \mathrm{P}_{0} \mathrm{~A}_{0}$ dengan usia perkiraan kehamilan 89 bulan serta ditemukan Kondiloma Akuminata. Saat mengetahui akan kehamilannya, pasien merasa kesal, cemas, dan malu. Pasien merasa malas beraktivitas semenjak hamil dan lebih banyak menghabiskan waktu di atas tempat tidur. Pemeriksaan psikometri didapatkan hasil Tes IQ yang sangat rendah (profound), skor total Strength and Difficulty Questionnaire (SDQ) 16; dan skor Prenatal Attachment Inventory (PAI) sebesar 31. Dari kasus tersebut dapat disimpulkan bahwa pengukuran prenatal
\end{abstract}


attachment dapat dijadikan prediktor bagaimana kelekatan ibu-anak yang mungkin terjadi setelah masa kelahiran dimana dapat mempengaruhi kesejahteraan, pertumbuhan, sosio-emosional, serta perilaku pada anak. Instrumen prenatal attachment bermanfaat sebagai alat skrining bagi calon ibu yang masuk dalam kategori populasi rentan (vulnerable population) seperti pada calon ibu dengan disabilitas intelektual serta komorbiditas yang lain guna pemilihan tata laksana yang lebih tepat.

Kata Kunci: prenatal attachment; kehamilan remaja; gangguan penyesuaian; retardasi mental

*Korespondensi: Frilya Rachma Putri. Surel: frilya.putri@gmail.com

\section{PENDAHULUAN}

Prenatal Attachment (PA) didefinisikan sebagai keterikatan yang abstrak dan bersifat satu arah antara orang tua terhadap calon bayi dalam masa kehamilan(1). Perasaan ini dapat bermanifestasi sebagai perilaku serta kapasitas kognitif terhadap calon bayi; seperti contoh: perencanaan nama bayi, mengelus-elus perut, berbicara dengan calon bayi, rutin melakukan pemeriksaan antenatal, serta melakukan persiapan kelahiran. Hubungan antara calon orang tua dan bayinya ini mempunya peran yang penting dalam kesejahteraan bayi baik ketika masih dalam kandungan maupun ketika sudah lahir. Beberapa penelitian menyebutkan bahwa PA memiliki hubungan erat terhadap bagaimana seorang ibu akan menggunakan kemampuan dan pengetahuannya untuk menyiapkan diri dalam melakukan kewajiban terkait perannya sebagai ibu, termasuk di dalamnya perilaku hidup sehat demi calon bayi $(2,3)$. Maka dari itu, tingkat $\mathrm{PA}$ yang tinggi merupakan prediktif kuat dari ibu yang mempunyai kesadaran tinggi akan kesejahteraan bayinya di mana akan terus berupaya dalam pemenuhan kebutuhan si bayi. Di sisi lain, tingkat PA yang rendah merupakan prediktif kuat akan terjadinya gangguan pada perkembangan, sosio-emosional, serta perilaku pada masa anakanak(4,5). PA dalam masa kehamilan berkembang secara bertahap dan dapat bervariasi antar individu karena dipengaruhi oleh berbagai faktor. Beberapa di antaranya adalah umur ibu, riwayat kehamilan, faktor sosio-ekonomi, hubungan pernikahan, kesehatan mental ibu, serta lingkungan sekitar ibu (4).

Ketika perkembangan PA dalam kondisi normal saja tidak serta merta bertumbuh karena memiliki potensi gangguan akibat tantangan dari faktor-faktor yang telah disebutkan sebelumnya, kehamilan dengan keadaan khusus seperti kehamilan pada remaja disertai gangguan psikologis lain tentunya akan memberikan tantangan yang berlipat ganda. Kehamilan pada remaja contohnya, mereka dihadapkan dengan stigma negatif dari masyarakat dan juga tuntutan untuk menjadi pengasuh utama calon bayi sedangkan kemampuan kognitif dan sosio-emosional untuk hal tersebut belum matur $(6,7)$. Hal tersebut sering kali menyebabkan prevalensi gangguan penyesuaian bahkan gangguan depresi pada kehamilan remaja menjadi 
meningkat dibanding remaja yang sedang tidak hamil $(7,8)$. Kesulitankesulitan tersebut pada akhirnya akan mempengaruhi seberapa besar PA akan tumbuh antara ibu dan calon bayi. Hal itu juga secara langsung berpengaruh pada kesiapannya dalam masa sebelum dan sesudah kelahiran yang selanjutnya berefek kepada kesejahteraan bayi.

Prenatal Attachment Inventory (PAI) yang merupakan instrumen untuk mengukur PA memiliki tingkat reliabilitas dan validitas yang cukup tinggi dalam aspek konsistensi internal, validitas konten, dan validitas konstruksi (concurrent validity dan predict validity) (9). Analisis faktor konfirmatori dari PAI menunjukkan bahwa seluruh pertanyaan memiliki nilai factor loading yang signifikan. Tidak didapatkan negative error variances, tidak didapatkan faktor korelasi lebih dari satu, serta nilai varians eror yang terlalu tinggi. Indikator reliabilitas berkisar antara 0.2 sampai 0.5 . Terlebih lagi, correlation matrix mengindikasikan seluruh pertanyaan pada PAI secara signifikan berhubungan antara satu dengan yang lain di $p<0.01$. Keseluruhan 21 pertanyaan pada instrumen ini menjelaskan $79 \%$ dari varians maternal fetal attachment (MFA). (10)

\section{KASUS}

Seorang perempuan usia 15 tahun dibawa ke rumah sakit untuk keperluan permintaan visum et repertum pada Januari 2018. Keluarga pasien melaporkan bahwa pasien mengalami pelecehan seksual 4 minggu sebelum datang ke rumah sakit. Dari pemeriksaan fisik didapatkan keadaan umum pasien baik dengan kesadaran compos mentis. Tanda vital terukur normal serta status gizi juga baik dengan perawakan normal. Pasien hamil $G_{1} P_{0} A_{0}$ dengan usia perkiraan kehamilan 8-9 bulan serta ditemukan adanya jengger ayam pada kemaluannya yang terkonfirmasi sebagai Kondiloma Akuminata.

Diduga pelaku pelecehan adalah pacar pasien yaitu seorang laki-laki dengan inisial ' $M$ ' yang berusia lebih tua beberapa tahun dari pasien (usia pasti tidak diketahui) dengan profesi sebagai pengemudi kontainer. Pada Agustus 2017 sekitar satu minggu setelah mulai berpacaran, pasien diajak melakukan hubungan badan dengan pacarnya. Frekuensi kejadian sekitar dua kali seminggu selama satu bulan. Hubungan badan dilakukan di kantor pelaku yang disebutnya sebagai "garasi". Hal itu diakui dilakukan dengan sukarela, namun pelaku mengancam akan membunuh ibu pasien jika melaporkan kejadian tersebut kepada siapapun. Sebelumnya, pasien juga pernah berhubungan badan dengan laki-laki lain, inisial $S$ dan $F$, yang usianya lebih tua dari pasien serta berprofesi sebagai pengemudi kontainer.

Dari wawancara didapati bahwa pasien tidak paham akan konsekuensi atau dampak dari berhubungan badan. Pasien percaya saja saat dijelaskan pelaku bahwa dirinya tidak akan hamil. Maka dari itu, pasien tidak menyadari ketika muncul tandatanda bahwa dirinya sedang mengandung. Pasien mengalami 
haid terakhir di bulan Agustus 2017, namun baru disadari bahwa sedang mengandung saat ibu pasien curiga perut pasien mulai membesar pada Januari 2018. Pasienpun juga tidak pernah melakukan pemeriksaan antenatal rutin dengan alasan ekonomi. Diketahui bahwa pasien pernah mencoba menggugurkan kandungan dengan mengkonsumsi jamu sebanyak 2 kali tetapi janin tidak luruh.

Sejak mengetahui bahwa dirinya hamil, pasien cenderung sering cemas dan bingung apabila diajak berbicara. Pasien mengungkapkan bahwa dirinya merasa kesal karena hamil dan benci akan ayah dari bayinya tersebut. Diapun merasa ingin bayinya segera lahir karena tidak ingin berlama-lama hamil. Selain itu, ia juga merasa tidak siap menjadi seorang ibu karena tidak tahu bagaimana cara merawat bayi. Ditambah lagi, ia juga merasa malu, minder, dan tertekan jika bertemu dengan teman-temannya. Pasien takut mereka melihat perutnya membesar sehingga ia menolak pergi ke sekolah. Hal itu juga dikarenakan takut akan ejekan dan stigma negatif yang mungkin diterima dari teman-teman. Pasien berencana untuk kembali sekolah hanya ketika anaknya sudah lahir. la merasa malas beraktivitas semenjak hamil dan lebih banyak menghabiskan waktu di atas tempat tidur. Pasien juga merasa badannya sakit semua.

Dari pemeriksaan status mental didapatkan penampilan seorang anak remaja perempuan, sesuai usia, perawakan sedang, berkulit sawo matang dengan rambut ikal, perawatan diri cukup, tampak mengantuk dan acuh tak acuh terhadap situasi sekitar. Berdasarkan pengamatan perilaku dan aktivitas motorik selama wawancara, pasien terlihat tenang tetapi terdapat perlambatan psikomotor dan tampak malasmalasan. Sikap pasien terhadap pemeriksa cukup kooperatif. Saat pasien diajak wawancara maka ia akan cenderung lamban menjawab, terlihat bengong, dan sering menanyakan ulang pertanyaan yang ditanyakan. Terdapat suasana perasaan cemas dan depresi dengan afek yang terbatas dan serasi. Pasien lebih banyak menjawab tidak tahu. Saat pemeriksaan tidak ditemukan gangguan persepsi. Proses pikir pasien koheren. Sedangkan isi pikir pasien cenderung terbatas. Pasien kurang dapat memertahankan konsentrasi dan perhatian selama pemeriksaan. Terdapat kesan bahwa kecerdasan pasien tidak sesuai dengan anak seusianya.

Dari pemeriksaan psikometri didapatkan hasil Tes IQ berupa kapasitas intelektual yang nampak adalah sangat Rendah (profound) dalam kelompok anak usianya. Hal ini diindikasikan oleh hasil pemeriksaan inteligensi di persentil 5 (skala SPM). Pasien mempunyai kapasitas intelektual dibawah normal dan lebih lambat daripada anak-anak lain dalam kelompok usianya. Skor total dari tes Strength and Difficulties Questionnaire (SDQ) yang didapatkan adalah 16 yang mengindikasikan masalah emosional dan perilaku yang substansial. Dari penilaian prenatal attachment yang menggunakan instrumen Prenatal Attachment Inventory (PAI) didapatkan skor sebesar 31 yang mengindikasikan rendahnya prenatal attachment 
yang dimiliki pasien terhadap janin yang dikandungnya.

\section{DISKUSI}

Pada kasus ini pasien adalah seorang remaja yang sedang hamil dengan riwayat kekerasan seksual. Pasien cenderung memiliki perasaan yang negatif akan kehamilannya, seperti cemas, minder, benci, malu dan kesal. Sering kali penyintas sexual violence related pregnancy (SVRP) menggambarkan kehamilannya sebagai ambivalensi maternal yaitu sulit untuk memisahkan pengalaman kekerasan seksual dari entitas bayi yang sedang dikandungnya (11). Sehingga, terdapat perasaan marah, cemas, dan sedih terhadap kehamilan tersebut karena mengingatkan kembali akan pengalaman atau individu yang berperan dalam kekerasan seksual yang menyakitkan bagi mereka(12). Lebih lanjut, penyintas SVRP juga merasa asing dengan kehamilannya karena merasa dipaksakan kepadanya (teralienasi) (13). Tidak jarang kasus-kasus seperti pada pasien ini mengarah kepada gangguan psikologis seperti gangguan penyesuaian atau bahkan gangguan depresi. Terlebih pada kasus ini di mana pasien merupakan SVRP yang masih dalam usia remaja sehingga komorbiditas gangguan penyesuaian atau gangguan depresi semakin meningkat.

Adanya perasaan yang cenderung negatif akan kehamilannya mengindikasikan prenatal attachment pada pasien ini kurang berkembang. Terlebih lagi ketika pemeriksaan dilakukan, usia kehamilan pasien sudah memasuki trimester ketiga di mana seharusnya PA pada seorang calon ibu memiliki tingkat yang paling tinggi. Hal ini semakin dikuatkan dengan skor PA yang diukur menggunakan PAI didapatkan total 31 poin di mana angka tersebut masuk dalam kategori rendah.

Penyintas SVRP, sama halnya dengan ibu hamil yang lain, menghadapi tiga pilihan terkait dengan kehamilannya yaitu pengasuhan (parenting), adopsi, atau terminasi. Meskipun dibutuhkan penelitian lebih lanjut, PA dapat menjadi prediktor seorang ibu hamil secara umum dan penyintas SVRP khususnya dalam pengambilan keputusan tersebut. Dalam kasus ini, sesuai dengan rendahnya $P A$, pasien merasa ingin kehamilannya cepat selesai dan mengindikasikan untuk memberikan bayinya agar diadopsi setelah lahir. Hal lain yang dapat diprediksi adalah pasien tidak berusaha dengan sungguh-sungguh dalam menjaga kehamilan serta persiapan kelahirannya dengan kontrol kehamilan yang tidak rutin serta sering merasa malas sehingga hanya berada di kasur seharian. Kendala lain dari berkembangnya PA pada pasien ini kemungkinan besar berkaitan dengan status sosioekonomi yang rendah, tingkat kecerdasan kurang, serta moral superego yang belum terkistralisasi.

Khusus pada aspek retardasi mental, menarik untuk dibahas karena merupakan faktor penyulit yang menyebabkan kasus ini menjadi kompleks. Dari beberapa penelitian menyebutkan bahwa seseorang dengan disabilitas intelektual seperti pada retardasi 
mental membutuhkan pendampingan dalam menjalani kehamilan serta masa-masa perinatal (14-16). Hal ini dikarenakan tanpa adanya intervensi, anak dengan orang tua yang memiliki disabilitas intelektual memiliki resiko terpapar dengan pengasuhan yang neglectful yang dapat menyebabkan gangguan kesehatan, pengembangan, dan perilaku (15). Namun, tidak serta merta orang tua dengan disabilitas intelektual tidak memiliki kapasitas dan kompetensi dalam pengasuhan anak seperti pendapat umum yang diyakini oleh masyarakat luas. Sehingga sering kali otoritas ibu dengan disabilitas intelektual direnggut dan keputusan mengenai kehamilan serta pengasuhan anak diambil oleh kerabat terdekat. Sedangkan salah satu penelitian menyebutkan bahwa, tanpa adanya komorbiditas yang lain, wanita dengan disabilitas intelektual mendalami pengalaman kehamilan, kelahiran, serta perinatal sama seperti wanita tanpa disabilitas intelektual (16). Pendampingan berupa simplifikasi informasi antenatal serta pelatihan pengasuhan memiliki peluang untuk meningkatkan kapasitas dan kompetensi ibu dengan disabilitas intelektual dalam pengasuhan anak (15).

Maka dari itu, penulis berpandangan bahwa diperlukan penelitian lebih lanjut guna menentukan algoritma tata laksana yang cocok digunakan pada ibu hamil dengan disabilitas intelektual. Instrumen PAI untuk mengukur PA berpotensi menjadi salah satu alat skrining awal dalam menentukan algoritma tersebut. PA yang tinggi mengindikasikan bahwa pasien mengantisipasi kedatangan makhluk hidup baru yang perlu dirawat sehingga kemungkinan pasien hanya perlu pendampingan dan pelatihan pengasuhan bayi. Sedangkan dengan hasil PA yang rendah mengindikasikan adanya kemungkinan komorbiditas yang perlu ditangani terlebih dahulu sebelum diberikannya pendampingan serta pelatihan pengasuhan. Dengan begitu, perlu diakukan uji validasi serta uji reliabilitas instrumen PAI ke dalam versi terjemahan bahasa indonesia yang sesuai dengan karakteristik budaya indonesia.

\section{KESIMPULAN}

Pengukuran prenatal attachment dapat dijadikan prediktor bagaimana kelekatan ibu-anak yang mungkin terjadi setelah masa kelahiran dimana dapat mempengaruhi kesejahteraan, pertumbuhan, sosioemosional, serta perilaku pada anak. Prenatal Attachment Inventory (PAI) yang merupakan instrumen untuk mengukur PA memiliki tingkat reliabilitas dan validitas yang cukup tinggi dalam aspek konsistensi internal, validitas konten, dan validitas konstruksi (concurrent validity dan predict validity) (9). Keseluruhan 21 pertanyaan pada instrumen ini menjelaskan $79 \%$ dari varians maternal fetal attachment (MFA). (10) Tim penulis menilai perlu dilakukan uji validitas serta reliabilitas untuk instrumen PAI versi bahasa Indonesia agar dapat digunakan sebagai alat pengukur PA pada ibu hamil di Indonesia.

\section{DAFTAR PUSTAKA}

1. Rollè L, Giordano $M$, 
Santoniccolo F, Trombetta T. Prenatal attachment and perinatal depression: A systematic review. Int J Environ Res Public Health. $2020 ; 17(8)$.

2. Delavari M, MohammadAlizadeh-Charandabi S, Mirghafurvand $\mathrm{M}$. The relationship between maternal-fetal attachment and maternal self-efficacy in Iranian women: a prospective study. J Reprod Infant Psychol [Internet]. 2018;36(3):302-11. Available from:

https://doi.org/10.1080/02646 838.2018.1436753

3. Casale L. The Impact of the Antenatal Class 'Baby World' on the Caregiver -Infant Relationship - A Pilot Study. University of Hertfordshire; 2011.

4. Arguz Cildir D, Ozbek A, Topuzoglu A, Orcin E, Janbakhishov CE. Association of prenatal attachment and early childhood emotional, behavioral, and developmental characteristics: A longitudinal study. Infant Ment Health J. 2020;41(4):517-29.

5. Branjerdporn G, Meredith P, Strong J, Garcia J. Associations Between Maternal-Foetal Attachment and Infant Developmental Outcomes: A Systematic Review. Matern Child Health J. 2017;21(3):540-53.

6. Lucas G, Olander EK, Ayers $S$, Salmon D. No straight lines
- Young women's perceptions of their mental health and wellbeing during and after pregnancy: A systematic review and meta-ethnography. BMC Womens Health. 2019;19(1).

7. Hodgkinson S, Beers L, Southammakosane C, Lewin A. Addressing the mental health needs of pregnant and parenting adolescents.

Pediatrics. 2014;133(1):11422.

8. Freed $\mathrm{P}$, SmithBattle L. Promoting teen mothers' mental health. MCN Am J Matern Nurs. 2016;41(2):849.

9. Branjerdporn $G$, Meredith $P$, Wilson T, Strong J. Prenatal Predictors of Maternal-infant Attachment. Can J Occup Ther. 2020;87(4):265-77.

10. Lee MGT. Con struct Valid ity of the Pre na tal Attach ment Inven tory: A Con fir ma tory Fac tor Anal y sis Approach. 2003;11(3):177-87.

11. Scott J, Onyango MA, Burkhardt G, Mullen C, Rouhani S, Haider S, et al. A qualitative analysis of decision-making among women with sexual violencerelated pregnancies in conflict-affected eastern Democratic Republic of the Congo. BMC Pregnancy Childbirth. 2018;18(1):1-9.

12. Scott J, Mullen C, Rouhani S, Kuwert P, Greiner A, Albutt K, et al. A qualitative analysis of psychosocial outcomes among women with sexual 
violence-related pregnancies in eastern Democratic Republic of Congo. Int J Ment Health Syst. 2017;11(1):1-10.

13. Perry R, Murphy M, Haider S, Harwood B. One Problem Became Another: Disclosure of Rape-Related Pregnancy in the Abortion Care Setting. Women's Heal Issues [Internet]. 2015;25(5):470-5. Available from: http://dx.doi.org/10.1016/j.whi. 2015.05.004

14. Feldman MA, Aunos M. Recent Trends and Future Directions in Research Regarding Parents with Intellectual and Developmental Disabilities. Curr Dev Disord Reports. 2020;7(3):173-81.

15. Coren E, Ramsbotham K, Gschwandtner M. Parent training interventions for parents with intellectual disability. Cochrane Database Syst Rev. 2018;2018(7).

16. Homeyard C, Montgomery E, Chinn D, Patelarou E. Current evidence on antenatal care provision for women with intellectual disabilities: A systematic review. Midwifery [Internet]. 2016;32:45-57. Available from: http://dx.doi.org/10.1016/j.mid w.2015.10.002 